\title{
Introduction: Understanding Indonesia
}

Stephen J. Epstein

Victoria University of Wellington

This special issue of the Journal of Indonesian Social Sciences and Humanities (JISSH) has its origins in a series of seminars jointly sponsored in 2005 and 2006 by the Asian Studies Institute (ASI) of the Victoria University of Wellington and the Indonesian Embassy in New Zealand. Although many papers from those seminars appeared in institute proceedings, the audience remained largely confined to New Zealand, despite the presence of fine articles that have deserved wider circulation. We are pleased here to offer new versions of some of those essays, updated in the light of recent developments, along with specially commissioned contributions.

The particular theme of those joint seminars was "Understanding Indonesia," and as I write the introduction to this special issue, the apparent ambition of that title strikes me once again with diffidence. Understanding Indonesia? How can one hope to "understand" Indonesia in any meaningful sense? Was this title a foolhardy choice on our part? A phrase with the potential to be misread as an arrogant claim? The five articles here, though treating within the Indonesian context such a broad variety of topics as foreign policy and Islam, local vs. national identity, gender and democracy, popular culture and class, and economic nationalism, obviously present no more than a very limited set of partial understandings - glimpses, if you will, into a nation of enormous complexity.

Nonetheless, the title is perhaps not so unreasonable, if considered from a different perspective: modest as the ultimate result may be, this volume presents the work of specialists who are attempting at an explicit level 
to dispel a common practice not only in New Zealand but further afield of "Misunderstanding Indonesia." It is fair to say, unfortunately, that Indonesia has had an image problem in many countries, New Zealand not least among them. A host of pernicious stereotypes frequently resurface in local media coverage of Indonesia, despite - or perhaps because of-Indonesia's status as New Zealand's closest Asian neighbour. Even when not succumbing to negative imagery, media treatment is often superficial and subject to bias. As then Ambassador Primo Alui Joelianto noted in his opening address for one seminar, at times it seems that the New Zealand public's understanding of Indonesia has stood in inverse relationship to its relative geographic proximity. Promoting more nuanced views of one of the world's most remarkable nations needs support.

Of course, it also must be recognised that even specialists face serious challenges in understanding Indonesia. It is difficult enough to develop a deep understanding of smaller, more homogenous social units such as an ethnic community, a city, or even a village, let alone a nation of Indonesia's diversity. If I compare Indonesia with South Korea, my primary field within Asian Studies, I would note that scholars of the latter nation often have to deconstruct totalising discourses suggesting that South Korea is a monolithic, somehow graspable entity. To be sure, the Korean peninsula existed for several centuries as an integrated political unit until its division after World War II, and, at least in some senses, contemporary South Korea functions not unlike an enormous city-state. Roughly 50 per cent of the nation's population now lives within the Seoul greater metropolitan area. Communication networks and continuing development of transport infrastructure create a ready web of links that draw the nation into an ever smaller compass. Dialects persist, but as recognisable variants of a common language. Popular consciousness has frequent recourse to the notion of a single bloodline (tanil minjok) for the Korean people. Little wonder that Koreanists at times must combat a belief that deeper understanding of South Korea primarily involves peeling away layers and moving towards a core essence. 
Understanding Indonesia, by contrast, as often pointed out, requires appreciating the challenges faced by a nation-state containing, very literally, hundreds of languages and distinct ethnicities - an "extremely vast and complex...jigsaw puzzle", in the words of volume author Dewi Fortuna Anwar. If South Korea, rightly or not, metaphorically becomes an onion in the framework described above, then Indonesia is a mixed salad with a stunning variety of ingredients. To travel from the most remote mountain settlement in South Korea to Seoul can readily be accomplished within a day; even with plane flights, however, to travel from, say, an isolated town in Sumatra to a village in Papua might require days on the road. But even far briefer movement can entail striking shifts: one of my most memorable and illuminating experiences in Indonesia was to be invited, on consecutive days, to attend first a funeral in upland Christian-animist Tana Toraja, and then a wedding less than 100 kilometers down the road in Enrekang, whose Muslim inhabitants fall within a larger Bugis-Makassarese ethnic cluster. Each area is of course well-known for its respective celebrations of these crucial life passages, and the striking contrast within twenty-four hours brought home at a visceral level not only Indonesia's kaleidoscopic variety of cultures but also the challenges the country faces in imagining a coherent national community. As Graeme MacRae notes in his article here "If Indonesia is Too Hard to Understand, Let's Start with Bali", even for a citizen-subject, grasping Indonesia is difficult.

How indeed do the people of Indonesia make sense of their own nation? Just to cite one common strategy from my own excursions into literary translation, cultural productions can simultaneously reinforce and problematise particular notions of Indonesian identity. In "I Want to Live" (Aku Mau Hidup), for example, a short story set amidst the upheavals of 1998 that brought down the Soeharto regime, Indonesian author in exile Rondang Erlina Marpaung has her protagonist set forth a proud humanistic doctrine: "Tell your children that we love Indonesia, our country, that we love wisdom and democracy. Tell them the usual things: that our country holds 13,000 islands scattered over 5,000 kilometers of sea. Its inhabitants are Muslim, Christian, Hindu, 
Buddhist. Tell them that we must be able to live side by side with one another in peace." ${ }^{1}$ The words take on added resonance and no small irony, in that the speaker is a young Christian woman who has been gunned down during a demonstration and addresses these words from beyond the grave to the Muslim youth she loves.

The prismatic effects of the imagination play a determinant role in how people everywhere understand the world around them; the popular production and consumption of images engage in an ongoing dialectic that shapes discourse even as images are in turn shaped by that discourse. As mentioned above, however, understanding Indonesia becomes perhaps even more difficult, both internally and externally, because of negative images resulting from turmoil and what Dewi Fortuna Anwar terms here the " $\mathrm{CNN}$ effect' as graphic news of violence and conflicts are repeated over and over again, obscuring other realities." South Koreans may complain at times that memories of the Korean War continue to colour images of their country, and that North Korea, the South's estranged sibling, runs interference in any project of national branding; in Indonesia's case, the unfortunate repetition of terrorist incidents and sectarian clashes has an equally weighty effect on understandings of the nation, domestically and abroad.

Consider as another example the short story "Bom,"2 which Putu Wijaya, probably Bali's most noteworthy literary figure, posted on his blog in 2009. Here the author makes an intertextual reference to his own work (an earlier short story collection by the same title), but reality itself has thrown up a much more palpable and disturbing referent than the free flights of fancy that characterized the previous tales, as its protagonists struggle to make sense of the most recent bombing at the Jakarta Marriott. Putu Wijaya's use of the blogging medium itself suggests further changes in the propagation of imagery about Indonesia in the few short years since the Understanding Indonesia seminars: although the community reached by the author's work may remain linguistically

\footnotetext{
1 Rondang Erlina Marpaung, "I Want to Live" (Aku Mau Hidup) tr. By Stephen J. Epstein, Menagerie 6, 2004: 65.

2 http://putuwijaya.wordpress.com/2009/07/20/bom/
} 
bounded by the use of Bahasa Indonesia, its potentially international reach signals that developments in information and communication technology will bring about further evolution in how understandings of Indonesia are determined.

Certainly even in the Web 2.0 era, global understandings of Indonesia will remain conditioned by the nation's own contested, fragmented and developing understanding of itself, and all the papers here address this internal debate over identity in one way or another. Graeme MacRae, for example, who leads off, examines how the Balinese, a smaller ethnic group that stands apart from the majority in religious terms, find their place within the nation. MacRae highlights tensions between local and national identifications and multiple and overlapping senses of community in a manner that parallels and complements Wijaya's literary approach in "Bom". Bali's own recent experience of tragic bombings and the ensuing crisis of confidence have impelled many Balinese to query their self-understanding and their relationship to the larger national context in which they find themselves. MacRae discusses in detail the Ajeg Bali movement, which has aimed at restoring Bali to a perceived strong, upright position. As he notes, such projects are inextricably bound up with Balinese definitions vis-à-vis the Other, which look variously towards the West, towards Jakarta, towards Java and Lombok more generally, and particularly towards poorer Muslims who have migrated to the island in great numbers concomitant with the boom in Bali's tourism industry.

MacRae concludes with a question that should be extended to this issue of $J I S S H$ as a whole: what can we learn from the individual understandings of Indonesia presented here? The Ajeg Bali movement itself is highly contingent upon context and even in the few years since MacRae first published on the topic, much has changed in response to circumstance. Does a consideration of the topic, then, lead to "understanding Indonesia", or merely contribute to "imagining multiple Indonesias"? Of course, "understanding" and "imagination" are intertwined. The moment "Indonesia" is reified as something knowable, there is a risk of serious distortion. All who attempt to understand Indonesia must 
continually remind themselves that knowledge invokes constructs dependent upon one's position, and that these constructs are themselves perpetually being negotiated. This awareness must not, however, lead to a nihilistic decision to abandon the endeavor: the impulse to "understand Indonesia" remains not merely valid but necessary because of its real world consequences.

Dewi Fortuna Anwar gives a sense of precisely the real world consequences that are at stake in "Foreign Policy, Islam and Democracy in Indonesia," in which she updates her keynote address from a Wellington seminar focusing on that trio of topics. Although, as she notes, each can be considered in isolation, the linking of the three yields useful insights. Here Anwar provides an overview of the relations between Islam and democracy in Indonesia with particular reference to their implications for Indonesian foreign policy. Consideration of these themes again evokes, inevitably, the crucial issue of Indonesia's identity and its evolution in recent years. Quoting President Susilo Bambang Yudhoyono, she notes the importance of anchoring Indonesia's attempts at managing its international identity in a strongly rooted internal sense of self, not least because foreign policy is an extension of domestic politics.

In an international climate that offers challenges and opportunities, Anwar argues that Indonesia has seen potential to carve out a niche for itself as a bridge between the Islamic world and the West. In its attempt to do so, Indonesia engages in a nation-branding exercise and seeks to present an example of a society in which Islam, democracy and modernity go hand in hand, but in Anwar's reading this initiative is hampered by two factors: first, acts of religious intolerance including terrorist violence have undercut Indonesia's attempts to serve as a role model, and, secondly, despite having the world 's highest population of Muslims, Indonesia's peripheral status within the wider Islamic ummah impede efforts to become a leader. Her analysis provides a salutary reminder that understandings of Indonesia in a broader context remain dependent on external factors such as international images of Islam, 
and that a global understanding of the nation must take into account constituencies beyond the West.

In "Participating in Parliamentary Politics: Experiences of Indonesian Women 1995-2010," Sharyn Graham Davies and Nurul Ilmi Idrus move the question of understanding contemporary Indonesia in a different direction as they discuss female experience, concentrating on participation in the political sphere. By contextualising their examination of women's participatory rates in parliament within a wider consideration of female participation in politics and the public sphere more generally, their focus broadens to shed light upon several important issues in evolving gender relations from the latter years of the New Order until the present. Their analysis exposes contradictions that require unpacking: understanding Indonesia requires reconciling the significant influence that women have traditionally wielded with their low rates of participation in governmental roles.

Thee Kan Wie of the Indonesian Institute of Sciences also calls attention to the need for similarly broad perspectives in his article "Understanding Indonesia: the Role of Economic Nationalism," as he surveys the role that nationalism has played in economic policy from Independence until the present. Thee's explorations again relate to the question of identity at a fundamental level: how does Indonesia understand itself in relation to the rest of the world? How does it demarcate the boundaries of the nation? Who and what counts as foreign and how have such definitions changed over time? Thee makes a compelling case for the determining effect that these questions have had in the economic sphere. After discussing how economic nationalism in the 1950s was directed particularly at continuing Dutch economic interests, he considers how ethnic Chinese were treated, an issue complicated by the fact that the category included not only Indonesian citizens, but citizens of the PRC and those who were loyal to Taiwan and stateless. He then moves on to the Malari incident of 1974 with its anti-Japanese sentiments, and the 1990s and the desire for strategic development of industries including high-tech that would reflect Indonesia's aspirations as an emerging 
power before turning in conclusion to the post-Soeharto era and critiques of IMF intervention.

Emma Baulch's article "Music for the Pria Dewasa: Changes and Continuities in Class and Popular Music Genres" treats identity issues from a thoroughly different perspective but becomes a surprisingly germane companion piece to Thee's in its treatment of how the normative Indonesian subject is constructed. Considering the arrival of the Indonesian version of Rolling Stone in terms of the intersections of media, popular music and what Baulch terms notions of "middleness", she opens up a view on the changing parameters of class in Indonesia and the role of the pria dewasa (adult male) within this system. In doing so, she stakes out a provocative position in running against the grain of much scholarship on the Indonesian middle class, which posits that quantifiable growth took place as a result of New Order economic policies. Baulch notes that she resists the idea that "an Indonesian middle class identity can be singularly associated with the political vision of those groups of intellectuals who supported the establishment of the regime, then became disillusioned with it." Her complex reading of Indonesian mythologies of middleness and the discursive structures that have underpinned it in popular culture provide another illuminating avenue for understanding Indonesia.

Some final remarks to conclude this brief introduction: the five years since the "Understanding Indonesia" seminar series was launched have given cause for optimism that Indonesia's image is improving in New Zealand and further afield. The period, roughly coterminous with SBY's first term, can also be seen as successful to the extent that Indonesians returned their president to office in open elections that suggested a substantial vote of confidence. The ongoing process of Reformasi, though requiring the balancing of pre-existing norms and the emergence of new forces, including an ever more vibrant civil society, continues apace. It is a striking mark of how far the nation has traveled from authoritarianism to democracy that it now eagerly encourages vigorous, often critical, debate, as witnessed in the Embassy's desire to partner with the Asian Studies Institute for the Understanding Indonesia series. 
It remains here to thank again the embassy as well as the many speakers in the series, and the contributors here who remind us that simple acknowledgements of the nation's diversity cannot get us far without knowledge of the specific contexts in which Indonesia operates; true understanding of Indonesia will always necessitate careful, nuanced empirical studies of the sort presented by JISSH. 